\title{
Anaerobic digestion and co-digestion of slaughterhouse wastes
}

\author{
Sonia Castellucci, ${ }^{1}$ Silvia Cocchi, ${ }^{2}$ Elena Allegrini, ${ }^{2}$ Luigi Vecchione ${ }^{2}$ \\ ${ }^{1}$ CIRDER, Università degli Studi della Tuscia, Italy; ${ }^{2}$ DAFNE, Università degli Studi della Tuscia, Italy
}

\begin{abstract}
The use of renewable energy is becoming increasingly necessary in order to address the global warming problem and, as a consequence, has become an high priority for many countries. Biomass is a clean and renewable energy source with growing potential to replace conventional fossil fuels. Among biomass, residual and waste ones represent a great resource for energy generation since they permit both to eliminate a possible waste and to produce energy. In the present work, the case of slaughterhouse wastes (SHWs) has been investigated. Anaerobic digestion is nowadays considered as one of the most important and sustainable conversion technology exploiting organic matter and biodegradable wastes. Biogas results from this bio-chemical process and mainly consists of methane and carbon dioxide, leading to produce thermal energy and/or electricity. In this paper, the European Regulations on animal by-products (ABPs) are described, and some previous study on anaerobic digestion and co-digestion of ABPs - more precisely SHWs - are considered and compared in order to fix a starting point for future tests on their co-digestion in a micro-scale pilot digester. This is to define optimal feed ratio values which ensure an increasing content of methane in the outgoing biogas.
\end{abstract}

\section{Introduction}

Renewable Energy Sources are increasingly used in order to reduce fossil fuels consumption and consequently those problems linked to global warming (N.L. Panwar et al., 2011). Nowadays, biomass are one of the most widespread sources which can be efficiently used to produce energy in different ways (P. McKendry, 2002). Among them, Anaerobic Digestion (AD) is one of the most interesting energy conversion methods. It involves bacterial fermentation and permits the

Correspondence: Silvia Cocchi, DAFNE, Università degli Studi della Tuscia, via San Camillo de Lellis snc, 01100 Viterbo (VT), Italy.

Tel. +39.0761 .401343 .

E-mail: silvia.cocchi@unitus.it

Key words: anaerobic digestion, biogas, slaughterhouse wastes, animal byproducts.

(C) Copyright S. Castellucci et al., 2013

Licensee PAGEPress, Italy

Journal of Agricultural Engineering 2013; XLIV(s2):e104

doi:10.4081/jae.2013.s2.e104

This article is distributed under the terms of the Creative Commons Attribution Noncommercial License (by-nc 3.0) which permits any noncommercial use, distribution, and reproduction in any medium, provided the original author(s) and source are credited. organic matter decomposition in an oxygen free environment (A. J. Ward et al., 2008). Biogas -primarily consisting of methane (40 - 70\%) and carbon dioxide with traces of other gases- derives from $\mathrm{AD}$ process (T. Abbasi et al., 2012).

AD leads to several applications and involve different categories of feedstock, e.g. industrial and municipal waste-waters, agricultural, municipal, food industry wastes and plant residues. An attractive subject is the possible use on Animal By-Products (ABPs) too (A.J. Ward et al., 2008).

In the present paper, the European Regulations No 1069/2009 and No 142/2011 on ABPs are carefully described in order to identify which animal by-products can be used for biogas production. Furthermore several studies on SHWs anaerobic digestion and co-digestion have been considered and compared in order to fix a starting point for future laboratory tests. This plays a fundamental role if the slaughterhouse wastes produced in the Province of Viterbo have to be reused in a sustainable way by producing energy.

\section{Current regulations on animal by-products}

ABPs result from the slaughter of animals for human consumption, the production of dairy products, the disposal of dead animals and during disease control measures. Regardless of their origin, ABPs not intended for human consumption can determine a potential risk to public and animal health and to the environment. The disposal of all ABPs could lead to unbearable costs and risks for the environment which consequently need to be reduced. This problem might be successfully overcome by producing energy with ABPs in a sustainable way. (Regulation EC No 1069, 2009).

The Regulation (EC) No 1069/2009 of the European Parliament and of the Council lays down health rules with specific regard to ABPs and derived products not intended for human consumption. According to the law, ABPs are distinguished in three categories, depending upon the risk they pose towards human, animals and environment, and establishes their potential application (Table 1). Furthermore the corresponding treatments and uses for the treated ABPs categories are defined (Bayr et al., 2012a).

According to the above-mentioned regulation, the use in $\mathrm{AD}$ plants is allowed for Category 2 after or without pressure sterilisation depending on the type of ABPs - and Category 3. For "pressure sterilisation" it is meant the processing of ABPs, after reduction in particle size smaller than $50 \mathrm{~mm}$, to a minimum temperature of $133^{\circ} \mathrm{C}$ for at least 20 minutes and at an absolute pressure of at least 3 bar (Regulation EC No 1069/2009).

Actually in the Commission Regulation (EU) No 142/2011, implementing Regulation (EC) No 1069/2009, some uses for biogas production are considered for those products derived from processing materials belonging to Category 1 . In more detail, the latter products could be transformed into biogas; nevertheless, the digestion residues must be disposed by incineration or co-incineration, as Category 1 materials. If Category 1 materials are subjected to Alkaline hydrolysis pre-treatment, they could be transformed in a biogas plant and subsequently combusted 
rapidly at a minimum of $900^{\circ} \mathrm{C}$, followed by rapid chilling (quenching), but the transformation shall take place on the same site as the processing and in a closed system. Additionally in the case of high pressure hydrolysis pre-treatment, the product derived from Category 1 material could be used for biogas production, but the whole process must take place on the same site and in a closed system; the biogas produced must be combusted rapidly in the same plant as above explained for the alkaline hydrolysis case. Whereas the products derived from Category 2 and 3 processing can be used for biogas production without restrictions (Commission Regulation (EU) no 142, 2011).

According to Commission Regulation (EU) no 142/2011, a biogas plant must be equipped with a pasteurisation/hygienisation unit, which cannot be by-passed for ABPs or derived products introduced with a maximum particle size of $12 \mathrm{~mm}$ before coming into the unit. Nevertheless this unit is not mandatory if the ABPs are processed with the pre-treatments indicated in the Regulation for the specific categories and for some particular ABPs belonging to Category 2 and 3. In Table 2 some pre-treatments are reported.

\section{Anaerobic digestion of SHWs}

As indicated in EC 1069/2009, AD represents a treating possibility for $\mathrm{ABPs}$, in order to decrease the environmental impact and to produce energy from biogas for local uses. In this sense, $\mathrm{AD}$ is considered an interesting alternative for waste management (Banks and Wang, 1999). Furthermore, digestion effluents can be used as fertilizers in agriculture (Mata-Alvarez et al., 2000; Salminen et al., 2001; Zhang and Banks, 2012).

SHWs represent potentially an excellent substrate for anaerobic digestion because of their high content of lipids and proteins (Hejnfelt and Angelidaki, 2009). However, different studies have proved that the $\mathrm{AD}$ of these wastes is practicable only for low organic loading rate (OLR) and hydraulic retention time (HRT) (Salminen and Rintala, 2002) and is particularly prone to failure because of the production of inhibitory compounds: ammonia, volatile fatty acids (VFAs) and long chain fatty acids (LCFAs) (Salminen and Rintala, 2002a; Bayr et al., 2012b; Heinfelt and Angelidaki, 2009; Edstrom et al., 2003; Masse et al., 2002; Broughton et al., 1998; Lokshina et al., 2003).

Co-digestion of SHWs with other biomass, containing low content of nitrogen and/or lipids, permits to improve the process stability and methane production (Bayr et al., 2012a; Salminen et al., 2003; Rosenwinkel and Meyer, 1999).

A two-phase digestion system might represent an alternative solution leading to increase process efficiency, solid reduction, chemical oxygen demand (COD) removal and conversion in biogas (Wang and Banks, 2003; Banks and Wang, 1999).

Several tests were carried out in order to obtain a profitable $\mathrm{AD}$ process for biogas production. Thus, evaluations on different parameters variation were investigated as follows: pressure and temperature increases in $\mathrm{AD}$ processes or in pre-treatments, but without good results (Cuestos et al., 2010); an increase of lipids or a change of the bacterial community structure, with discrete results (Palatsi et al., 2011). Other studies evaluated the saponification of lipids in SHWs during pre-treatments and the use of ethanol biodegradation: a biogas improvement and, in some cases, the kinetic reactions were shown. However, the results are not enough clear to ensure the success of the process (Battimelli et al., 2009; Battimelli et al., 2010). Other studies concern the effects of influent flow rate variation on biogas production improvement both in BATCH anaerobic digesters (Resch et al., 2006) and in continuously stirred tank reactors (CSTRs) (Marcos et al., 2012).

Table 1. ABPs classification and allowed uses for biogas production according to Regulation (EC) No 1069/2009 of the European Parliament

\begin{tabular}{|c|c|c|}
\hline Category & Animal by-products & Biogas production \\
\hline 1 & $\begin{array}{l}\text { All body parts of the following animals: suspected of being infected by a TSE; pet, zoo and circus animals; } \\
\text { animals used for experiments; wild animals if suspected of being infected with diseases communicable } \\
\text { to humans or animals; contained specified risk material. ABPs derived from animals submitted to illegal } \\
\text { treatments or containing residues of other substances and environmental contaminants. ABPs collected } \\
\text { during waste-water treatments of plants processing Category } 1 \text { material or risk material. Catering wastes } \\
\text { from means of transport operating internationally. Mixture of Category } 1 \text { with Category } 2 \text { or } 3 \text { material }\end{array}$ & $\begin{array}{l}\text { Not allowed. } \\
\text { Allowed after specific pre-treatments, but provided } \\
\text { the digestion residues are disposed } \\
\text { of by incineration and co-incineration }\end{array}$ \\
\hline 2 & $\begin{array}{l}\text { Manure and digestive tract content; ABPs collected during waste-water treatments of plants processing } \\
\text { Category } 2 \text { material or from slaughterhouses. ABPs containing residues of authorised substances. ABPs } \\
\text { declared unfit for human consumption due to the present of foreign bodies. ABPs imported from a third } \\
\text { country and fail to comply with Community veterinary legislation. Animals or parts (different than Category } \\
1 \text { and } 3 \text { ) that slaughtered or killed other than for human consumption, foetuses, oocytes, embryos and } \\
\text { semen not for breeding purposes; dead-in-shell poultry. Mixture of Category } 2 \text { with } 3 \text { material. ABPs other } \\
\text { than Category } 1 \text { or } 3\end{array}$ & $\begin{array}{l}\text { Allowed after pressure sterilisation or in biogas } \\
\text { plant with pasteurisation and hygienisation unit. } \\
\text { Allowed without pre-treatments only } \\
\text { for specific ABPs of this Category }\end{array}$ \\
\hline 3 & $\begin{array}{l}\text { Carcases and parts of animals slaughtered or, in the case of game, fit for human consumption but not } \\
\text { intended for this use for commercial reasons. Carcases and the following parts of animal slaughtered } \\
\text { or game killed for human consumption: parts unfit for human consumption according to Community } \\
\text { legislation, heads of poultry, hides, skins, horns, feet, pig bristles, feathers. ABPs from poultry or } \\
\text { lagomorphs slaughtered on the farm. Bloods of animals slaughtered in a slaughterhouse and considered } \\
\text { fit for human consumption. ABPs arising from the production of products intended for human consumption. } \\
\text { Products of animal origin, foodstuffs, pet food or feeding stuffs ,no longer intended for human or animal } \\
\text { consumption for commercial reasons. Blood, placenta, wool, feathers, hair, horns, hoof cuts and raw milk, } \\
\text { aquatic animals, ABPs from aquatic animals. Eggs, egg by products, including egg shells. Adipose tissue from } \\
\text { animals slaughtered in a slaughterhouse. Catering wastes }\end{array}$ & $\begin{array}{l}\text { Allowed after pre-treatments } 1 \text { to } 6 \text { or } 7 \text { or in a plant } \\
\text { with pasteurisation and hygienisation unit. } \\
\text { Allowed without pre-treatments for specific ABPs } \\
\text { if authorised by the competent authority }\end{array}$ \\
\hline
\end{tabular}




\section{Mono and co-digestion of pig, poultry and cattle SHWs}

Several studies reports experiments on AD of pig SHWs. Tests in BATCH reactor - at $35^{\circ} \mathrm{C}$ - measured the following methane productions: $428 \mathrm{dm}^{3} \mathrm{CH}_{4} / \mathrm{kgVS}$ (Bayr et al., 2012a) and $580 \mathrm{dm}^{3} \mathrm{CH}_{4} / \mathrm{kgVS}$ (Rodriguez-Abalde et al., 2011). Methane potentials of 225-619 $\mathrm{dm}^{3} \mathrm{CH}_{4} / \mathrm{kgVS}$ were evidenced on different pig wastes - meat, bone flour, fat, blood, hair, meat, ribs, raw wastes - at 37 and $55^{\circ} \mathrm{C}$ in $\mathrm{BATCH}$ reactor (Hejnfelt and Angelidaki, 2009).

Experiment results on anaerobic mono-digestion in Continuously Stirred Tank Reactor (CSTR) are not attended, but tests on co-digestion shows the following results: five fractions of rendering wastes with poultry, cattle, pig slaughterhouse wastes with a methane production of $717 \mathrm{dm}^{3} \mathrm{CH}_{4} / \mathrm{kgVS}$ at $35^{\circ} \mathrm{C}$ (Bayr et al., 2012a); pig mixed SHWs with solid pig manure have a methane yield of $489 \mathrm{dm}^{3} \mathrm{CH}_{4} / \mathrm{kgVS}$ at $37^{\circ} \mathrm{C}$ (Hejnfelt and Angelidaki, 2009).

Experiments on mono-digestion of poultry SHWs in BATCH reactor shows a methane yield of $262-266 \mathrm{dm}^{3} \mathrm{CH}_{4} / \mathrm{kgVS}$ at $35^{\circ} \mathrm{C}$ (Bayr et al., 2012a). Whereas tests in CSTRs evidences a methane production of $520-550 \mathrm{dm}^{3} \mathrm{CH}_{4} / \mathrm{kgVS}$ at $35^{\circ} \mathrm{C}$ (Salminen and Rintala, 2002) and 600$700 \mathrm{dm}^{3} \mathrm{CH}_{4} / \mathrm{kgVS}$ at $34^{\circ} \mathrm{C}$ (Cuestos et al., 2008). The firsts values are obtained under mesophilic conditions in $2 \mathrm{dm}^{3}$ CSTR operating with $0.8 \mathrm{kgVS} / \mathrm{m}^{3} \mathrm{~d}$ with an HRT of 50 days.

A study on co-digestion of poultry SHWs with Organic Fraction of Municipal Solid Wastes (OFMSWs) - at $34^{\circ} \mathrm{C}$, in CSTR - reveals a methane potential of $400-500 \mathrm{dm}^{3} \mathrm{CH}_{4} / \mathrm{kg}$ VS.

A methane yield of $460 \mathrm{dm}^{3} \mathrm{CH}_{4} / \mathrm{kgVS}$ is reported for poultry waste at $35^{\circ} \mathrm{C}$ (Rodriguez-Abalde et al., 2011) and higher potential is obtained for offal: $210-910 \mathrm{dm}^{3} \mathrm{CH}_{4} / \mathrm{kgVS}$ at 35 and $55^{\circ} \mathrm{C}$ (Salminen et al., 2003).

Experiments on mono-digestion of bovine SHWs in BATCH reactor shows a methane yield of $572 \mathrm{dm}^{3} \mathrm{CH}_{4} / \mathrm{kgVS}$ at $35^{\circ} \mathrm{C}$ (Bayr et al., 2012a).

Methane yield of $270-350 \mathrm{dm}^{3} \mathrm{CH}_{4} / \mathrm{kgVS}$ have been measured during co-digestion of solid cattle and swine SHWs with fruit/vegetable wastes and solid cattle/swine manure; the test were carried out in mesophilic conditions $\left(35^{\circ} \mathrm{C}\right)$ in a CRST and showed that digestion with mixed substrates is better than with single substrates (Alvarez and Liden, 2008).

Methane yield of $400-500 \mathrm{dm}^{3} \mathrm{CH}_{4} / \mathrm{kgVS}$ has been measured during co-digestion of Poultry SHWs with organic fraction of municipal solid waste (OFMSW); the test were carried out in mesophilic conditions $\left(34^{\circ} \mathrm{C}\right.$ ) in a CRST ( Cuestos et al.,2008; 2009; 2010). At the beginning of study carried out in 2008, initial problems with accumulation of digestion intermediates occurred, but after an acclimation at low organic loading the mixture could be treated. A dilution of slaughterhouse material with fresh water was used in order to reduce the ammonia concentration.

Methane yield of $400-430 \mathrm{dm}^{3} \mathrm{CH}_{4} / \mathrm{kgVS}$ have been measured during co-digestion of $\mathrm{ABPs}$ from meat processing industry with sewage sludge; the test were carried out in mesophilic conditions $\left(35^{\circ} \mathrm{C}\right)$ in a CRST (Luste and Luostarinen, 2010).

Co-digestion of manure and rumen (Rosenwinkel and Mayer, 1999) and blood and rumen from cattle and pigs were studied in laboratory in a pilot-scale plant at $37^{\circ} \mathrm{C}$ and with heating pre-treatments (Edstrom $e t$ al., 2003).

A study using fruit and vegetable wastes to improve the nutrient balance in sequencing batch anaerobic digestion was carried out by Bouallagui et al. (Bouallagui et al.,2009).

Pitk et al. studied methane potential of category 2 and 3 SHWs rendering products: melt, decanter sludge, meat and bone meal, technical fat and flotation sludge from wastewater treatments; values in the range $390-978 \mathrm{dm}^{3} \mathrm{CH}_{4} / \mathrm{kgVS}$ were measured (Pitk et al., 2012).

\section{Pre-treatments effects on AD}

Several studies evaluated the difference between the biogas production starting from treated and un-treated SHWs.

Some studies were carried out in batch reactor, at $55^{\circ} \mathrm{C}$, and on different pig SHWs - meat, bone flour, fat, blood, hair, meat, ribs, raw

Table 2. Some of pre-treatments for ABPs before using in anaerobic digestion plants (Commission Regulation (EU) No 142, 2011)

\begin{tabular}{|c|c|c|}
\hline Category & Uses in biogas plants & Treatments \\
\hline $1-2-3$ & Standard treatment 1: pressure sterilisation & Particles size $\leq 50 \mathrm{~mm} ; \mathrm{T} \geq 133^{\circ} \mathrm{C}$ and pressure (absolute) $\geq 3$ bar for at least 20 minutes \\
\hline $1-2-3$ & Standard treatment 2 & $\begin{array}{l}\text { Particles size } \leq 150 \mathrm{~mm} ; \mathrm{T} \geq 100^{\circ} \mathrm{C} \text { for at least } 125 \text { minutes, } \mathrm{T} \geq 110^{\circ} \mathrm{C} \text { for at least } 120 \text { minutes, } \mathrm{T} \geq 120^{\circ} \mathrm{C} \\
\text { for at least } 50 \text { minutes }\end{array}$ \\
\hline $1-2-3$ & Standard treatment 3 & $\begin{array}{l}\text { Particles size } \leq 30 \mathrm{~mm} ; \mathrm{T} \geq 100^{\circ} \mathrm{C} \text { for at least } 95 \text { minutes, } \mathrm{T} \geq 110^{\circ} \mathrm{C} \text { for at least } 55 \text { minutes, } \mathrm{T} \geq 120^{\circ} \mathrm{C} \\
\text { for at least } 13 \text { minutes }\end{array}$ \\
\hline $1-2-3$ & Standard treatment 4 & $\begin{array}{l}\text { Particles size } \leq 30 \mathrm{~mm} \text { must be placed in a vessel with added fat: } \mathrm{T} \geq 100^{\circ} \mathrm{C} \text { for at least } 16 \text { minutes, } \\
\mathrm{T} \geq 110^{\circ} \mathrm{C} \text { for at least } 13 \text { minutes, } \mathrm{T} \geq 120^{\circ} \mathrm{C} \text { for at least } 3 \text { minutes }\end{array}$ \\
\hline $1-2-3$ & Standard treatment 5 & $\begin{array}{l}\text { Particles size } \leq 20 \mathrm{~mm} \text { must be heated until they coagulate and then pressed so that fat and water are } \\
\text { removed from the proteinaceous material. The latter must then be heated: } \mathrm{T} \geq 80^{\circ} \mathrm{C} \text { for at least } 120 \\
\text { minutes, } \mathrm{T} \geq 100^{\circ} \mathrm{C} \text { for at least } 60 \text { minutes }\end{array}$ \\
\hline 3 & Standard treatment 6 & $\begin{array}{l}\text { Specific treatment for Category } 3 \text { animal by-products originating from aquatic animal or aquatic } \\
\text { invertebrates only }\end{array}$ \\
\hline 3 & Standard treatment 7 & Other processing method authorised by the competent authority \\
\hline $1-2-3$ & $\begin{array}{l}\text { Alternative treatments } \\
\text { Alkaline hydrolysis process }\end{array}$ & $\begin{array}{l}\text { Materials resulting from processing may be transformed in a biogas plant and subsequently combusted } \\
\text { rapidly at a minimum of } 900^{\circ} \mathrm{C} \text {, followed by rapid chilling ('quenching'); for Category 1, the transformation into } \\
\text { biogas shall take place on the same site as the processing and in a closed system; }\end{array}$ \\
\hline $1-2-3$ & $\begin{array}{l}\text { Alternative treatment: } \\
\text { High pressure hydrolysis biogas process } \\
\text { After standard method } 1 \text {. }\end{array}$ & $\begin{array}{l}\text { In the case of starting material of Category } 1 \text {, the entire process must take place on the same site and in a } \\
\text { closed system and the biogas produced during the process must be combusted rapidly in the same plant at a } \\
\text { minimum of } 900^{\circ} \mathrm{C} \text { followed by rapid chilling (quenching) }\end{array}$ \\
\hline
\end{tabular}


wastes - subjected to the following treatments according to the European Regulation: pasteurization at $70^{\circ} \mathrm{C}$ for 1 hours, sodium alkali hydrolysis (50 or $100 \mathrm{~g} \mathrm{NaOH} / \mathrm{kgVS}$ ), sterilization at $133^{\circ} \mathrm{C}$ and $300 \mathrm{kPa}$ for 20 minutes; the results show that pre-treatments had no effect on methane yields (Hejnfelt and Angelidaki, 2009).

A methane potential of $351-381 \mathrm{dm}^{3} \mathrm{CH}_{4} / \mathrm{kgVS}$ was determined at $35^{\circ} \mathrm{C}$, for $\mathrm{AD}$ of meat and bone meat (Wu et al., 2009).

Conversely other studies show some effects of pre-treatments on $\mathrm{AD}$. A potential biogas yield of $1.14 \mathrm{l} \mathrm{biogas} / \mathrm{gVS}$ is measured for pasteurised SHWs ( 1 hour at $70^{\circ} \mathrm{C}$ ) is shown, whereas for un-pasteurised ones it is $0.31 \mathrm{l} \mathrm{biogas} / \mathrm{g}$ VS (the production is about fourfold in the pasteurised case) (Edstrom et al., 2003). A growth in methane potential of about 14$18 \%$ is shown for the same pre-treatment with particle sizes lesser than $12 \mathrm{~mm}$ and applied to mixture of daily manure and biowastes and in mesophilic conditions (Paavola et al., 2006).

Several pre-treatments were investigated in order to reduce the particle sizes and to promote the lipids solubilisation. An increase of hydrolysis rate was achieved through the following pre-treatments:

saponification at different temperatures $-60,120$ and $150^{\circ} \mathrm{C}$ - for 30 minutes and $\mathrm{AD}$ tests in mesophilic and thermophilic conditions in batch reactor and on fatty SHWs; the best performances were observed for the treatment at $120{ }^{\circ} \mathrm{C}$ (Battimelli et al., 2009;2010); enzymatic hydrolysis (Masse et al., 2003)

- $\quad$ enzymatic bio-augmentation (Cirne et al., 2006).

In order to prevent the LCFA inhibition some treatments were studied, such as the use of acclimated biomass (Cavailero et al., 2008), the supplement of adsorbent (biofibers or bentonite) (Palatsi et al., 2009), the use of feeding strategies with sequential LCFA accumulationdegradation steps (Cavaleiro et al., 2009).

Affes et al. evaluated different configurations for anaerobic monodigestion for fat from cattle carcasses in mesophilic conditions $\left(35^{\circ} \mathrm{C}\right)$. The system combines saponification wastes pre-treatments, $\mathrm{AD}$ in CSTR and solid recirculation. The studies are carried out with/without waste saponification pre-treatments (at $70^{\circ} \mathrm{C}$ for 60 minutes) and with/without digestate solid fraction recirculation. An enhancement on methane yield and COD degradation efficiency was achieved; the best performance was obtained in the reactor equipped with pre-treatments and recirculation. Indeed saponification enhances the emulsionification and bioavailability of solid fatty residues, whereas recirculation minimizes the substrate wash out and induces the microbial community adaption to the treatment of the lipid/LCFA based substrates (Affes et al., 2013).

\section{Conclusions}

The European Regulations describe carefully which SHWs could be used in $\mathrm{AD}$ plants and establishes potential applications without any restriction for category 3 only. As for category 2, some restrictions must be applied, whereas with regard to category 1 the use for biogas production is exceptional, complicated and permitted after specific pre-treatments only.

The analysis of different studies on $\mathrm{AD}$ of SHWs have shown that a good conclusion of the process can be achieved in mesophilic conditions, whereas it is considerably complicated in thermophilic conditions.

Furthermore co-digestion with other substrates determines better results than mono-digestion of SHWs.

As for pre-treatments effects on $\mathrm{AD}$ process, the results are debatable, since pre-treatments influence the biogas production yield according to some authors, whereas other authors demonstrate no effects on the process.
In order to exploit local SHWs by generating energy, future studies will concern co-digestion laboratory tests with different co-substrates. Nowadays, with specific regard to the Province of Viterbo, the following data on SHWs production are available: 2624,1 ton for cattle, 285,7 ton for pigs and 2167,5 ton for ovine and caprine (ISTAT, IZS).

The expected results will help to correctly size digesters in the Province of Viterbo.

\section{References}

Abbasi T, Tauseef SM, Abbasi SA. Anaerobic digestion for global warming control and energy generation-An overview. Renew Sust Energ Rev 2012;16:3228-42.

Affes R., Palatsi J, Flotats X., Carrère H, Steyer JP; Battimelli A. Saponification pre-treatment and solid recirculation as a new anaerobic process for the treatment of slaughterhouse waste. Bioresource Technol 2013;131:460-7.

Alvarez R, Liden G. Semi-continuous co-digestion of solide slaughterhouse waste, manure and fruit and vegetable wastes. Ren Energ 2008;33:726-34.

Banks CJ, Wang Z. Development of a two phase anaerobic digester for the treatment of mixed abattoir wastes. Water Sci Technol 1999; 40:69-76.

Battimelli A, Carrere H, Delgenes JP. Saponification of fatty slaughterhouse wastes for enhancing anaerobic biodegradability. Bioresource Technol 2009;100:3695-700.

Battimelli A, Torrijos M, Moletta R, Delgenes JP. Slaughterhouse fatty waste saponification to increase biogas yield. Bioresource Technol 2010;101:3388-93.

Bayr S, Rantanen M, Kaparaju P, Rintala J. Mesophilic and thermophilic anaerobic co-digestion of rendering plant and slaughterhouse wastes. Bioresource Technol 2012; 104:28-36.

Bayr S, Pakarines 0, Korppoo A, Liuksia S, Vaisanen A, Kaparaju P. Effect on additives on process stability of mesophilic anaerobic monodigestion of pig slaughterhouse waste. Bioresource Technol 2012;120:106-113.

Bouallagui H, Rachdi B, Gannoun H, Hamdi M. Meshopilic and thermophilic anaerobic co-digestion of abattoir wastewater and fruit and vegetable waste in anaerobic sequencing batch reactors. Biodegradation 2009;20:401-9.

Broughton MJ, Thiele JH, Birch EJ, Cohen A. Anaerobic batch digestion of sheep tallow. Water Res 1998;32:1423-28.

Cavaleiro AJ, Pereira MA, Alves M. Enhancement of methane production from long chain fatty acids based effluents. Bioresource Technol 2008;99:4086-95.

Cavaleiro AJ, Salvador AF, Alves JI, Alves M. Continuous high rate anaerobic tretament of oleic based wastewater is possible after a step feeding start-up. Environ Sci Technol 2009;43:2931-6.

Cirne DG, Bjornsson L, Alves MM, Mattiasson B. Effect of bioaugmentation by an anaerobic lipolytic bacterium on anaerobic digestion of lipid rich waste . J. Chem Technol Biotechnol 2006;81:1745-52.

Commission Regulation (EU) No 142/2011 of 25 February 2011 implementing Regulation (EC) No 1069/2009 of the European Parliament and of the Council laying down health rules as regards animal by-products and derived products not intended for human consumption and implementing Council Directive 97/78/EC as regards certain samples and items exempt from veterinary checks at the border under that Directive. In: Official Journal of the European Union No.54, 25/02/2011, pp 1-254.

Cuestos MJ, Gomez X, Otero M, Moran A. Anaerobic digestion of solid slaughterhouse wastes (SHW) at laboratory scale: influence of co- 
digestion with the organic fraction of municipal solide waste (OFMSW). Biochem Eng J 2008;40:99-106.

Cuestos MJ, Moran A, Gomez X, Otero M. Anaerobic co-digestion of poultry blood with OFMSW: FTIR and TG-DTG study of process stabilization. Environ Technol 2009;30:571-582.

Cuestos MJ, Gomez X, Otero M, Moran A. Anaerobic digestion and codigestion of slaughterhouse wastes (SHW): influence of heat and pressure pre-treatments in biogas yield. Waste Manage 2010;30:1780-89.

Edstrom M, Nordberg A, Thyselius L. Anaerobic treatment of animal byproducts from slaughterhouses at laboratory and pilot scale. Applied Biochem and Biotech 2003;109:127-38.

European Regulation (EC) No 1069/2009 of the European Parliament and of the Council of 21 October 2009 laying down health rules as regards animal by-products and derived products not intended for human consumption and repealing Regulation (EC) No 1774/2002 (Animal by-products Regulation). In: Official Journal of the European Union No.300, 21/10/2009, pp 1-33.

Hejnfelt A, Angelidaki I. Anaerobic digestion of slaughterhouse by products. Biomass and Bioenerg 2009;33:1046-54.

Lokshina LY, Vavilin VA, Salminen E, Rintala J. Modeling of anaerobic degradation of dolid slaughterhouse waste: inhibition effects of long-chain fatty acids or ammonia. Appl Biochem Biotechnol 2003;109:15-32.

Luste S, Luostarinen S. Anaerobic co-digestion of meat-processing byproducts and sewage sludge-effect of hygenization and organic loading rate. Bioresource Technol 2010;101:2657-64.

Marcos A, Al-Kassir A, Lopez F, Cuadros F, Brito P. Environmental treatment of slaughterhouse wastes in a continuously stirred anaerobic reactor: effect of flow rate variation on biogas production. Fuel processing Technol 2012;103:178-82.

Masse L, Massè DI, Kennedy KJ, Chou SP. Neutral fat Hydrolysis and long-chain fatty acids oxidation during anaerobic digestion of slaughterhouse wastewater. Biotechnol Bioeng 2002;79:43-52.

Masse L, Massè DI, Kennedy KJ. Effect of hydrolysis pretreatment on fat degradation during anaerobic digestion of slaughterhouse wastewater . Process biochem 2003;38:1365-72.

Mata-Alvarez J, Mace S., Llabres P. Anaerobic digestion of solide wastes. An overview of research achievements and perspectives. Bioresource Technol 2000; 74:3-16.

McKendry P. Energy production from biomass (part 2): conversion technologies. Bioresource Technol 2002;83:47-54.

Paavola T, Syvasalo E, Rintala J. Co-digestion of manure and bioeaste according to the EC animal by-products regulation and Finnish national regulations. Water Sci Technol 2006;53:223-31.
Palatsi J, Laureni M, Andres MV, Flotats X, Nielsen HB, Angelidaki I. Strategies for recovering inhibition caused by long chain fatty acids on anaerobic thermophilic biogas reactors. Bioresource Technol 2009;100:4588-96.

Palatsi J, Vinas M, Guivernau M, Fernandez B, Flotats X. Anaerobic digestion of slaughterhouse waste: main process limitations and microbial community interactions. Bioresource Technol 2011;102:2219-27.

Panwar NL, Kaushik SC, Kothari Surendra. Role of renewable energy sources in environmental protection: A review. Renew Sust Energ Rev 2011;15:1513-24.

Pitk P, Kaparaju P, Vilu R. Methane potential of sterilized solid slaughterhouse wastes. Bioresource Technol 2012;116:42-6.

Resch C, Grasmug M, Smeets W, Braun R, Kirchmayr R. Optimised anaerobic treatment of house-sorted biodegradable waste and slaughterhouse waste in a high loaded half technical scale digester. Water Sci Technol 2006;53:213-21.

Rodriguez-Abalde A, Fernandez B, Silvestre G, Flotats X. Effect of thermal pre-treatments on solid slaughterhouse waste methane potential. Waste Manage 2011; 31:1488-93.

Rosenwinkel KL, Meyer H. Anaerobic treatment of slaughterhouse residues in municipal digesters. Water Sci Technol 1999;40:101111.

Salminen E, Rintala J, Härkönen J, Kuitunen M, Högmander H, Oikari A. Anaerobically digested poultry slaughterhouse wastes as fertiliser in agriculture. Bioresource Technol 2001;78:81-8.

Salminen EA, Rintala JA. Semi-continuous anaerobic digestion of solid poultry slaughterhouse waste: effect on hydraulic retention time and loading. Water Res 2002;36:3175-82.

Salminen E, Einola J, Rintala J. The methane production of poultry slaughtering residues and effects of pretreatments on the methane production of poultry feather. Environ Technol 2003;24:1079-86.

Wang Z, Banks CJ. Evaluation of a two stage anaerobic digester for the treatments of mixed abattoir wastes. Process Biochem 2003;38:1267-73.

Ward AJ, Hobbs PJ, Holliman PJ, Jones DL. Optimisation of the anaerobic digestion of agricultural resources. Bioresource Technol 2008;99:7928-40.

Wu G, Healy MG, Zhan X. Effect of the solid content on anaerobic digestion of meat and bone meal. Bioresource Technol 2009;100:432631.

Zhang Y, Banks CJ. Co-digestion of the mechanically recovered organic fraction of municipal solid waste with slaughterhouse wastes. Biochem Eng J 2012;68:129-37. 